\title{
Production of Bacterial Cellulose from Acetobacter Species and Its Applications - A Review
}

\author{
C.P. Jamsheera $(\mathbb{D})$ and B.V. Pradeep* \\ Department of Microbiology, Karpagam Academy of Higher Education, Coimbatore - 641021 , \\ Tamil Nadu, India.
}

\begin{abstract}
Bacterial cellulose $(\mathrm{BC})$ is a natural polymer secreted as a protective cell covering of certain bacterial species. In contrary to plant cellulose, BC possesses some unique features like high moisture-holding capacity, high durability, high liquid absorbing capabilities, biostability, and biodegradability, makes BC an excellent raw material in wide-ranging areas like biomedical, food, agriculture, paper, textile industries and electronics. The main objective of this review is to discuss various aspects of $B C$ production (different sources for bacterial strain isolation, culture media and, its alternatives also major culture techniques). In addition, various applications of BC are also reviewed.
\end{abstract}

Keywords: Bacterial cellulose, Acetobacter sp, culture medium, Culture techniques, Applications

*Correspondence: bvpradeepku@gmail.com

(Received: March 25, 2021; accepted: May 23, 2021)

Citation: Jamsheera CP, Pradeep BV. Production of Bacterial Cellulose from Acetobacter Species and Its Applications - A Review. J Pure Appl Microbiol. 2021;15(2):544-555. doi: 10.22207/JPAM.15.2.48

(C) The Author(s) 2021. Open Access. This article is distributed under the terms of the Creative Commons Attribution 4.0 International License which permits unrestricted use, sharing, distribution, and reproduction in any medium, provided you give appropriate credit to the original author(s) and the source, provide a link to the Creative Commons license, and indicate if changes were made. 


\section{INTRODUCTION}

The most plentiful organic molecule in the biosphere is cellulose, an unbranched homopolymer of glucose. Fungal and algal cell walls are mainly composed of cellulose. It consists of a linear homopolysaccharide linked by $\beta 1,4$ glycosidic bonds ${ }^{1,2,3}$. Cellulose is also produced by a number of bacterial species, as a protective covering around their cell. The molecular formula for both plant and bacterial cellulose is the same $\left(\mathrm{C}_{6} \mathrm{H}_{10} \mathrm{O}_{5}\right) \mathrm{n}$ but they differ in their physicochemical properties. $\mathrm{BC}$ production is primarily by the utilization of various carbon sources in the culture media, though their rate of production can vary with various additives ${ }^{4}$. BC is synthesized by a multi- biosynthetic pathway catalyzed by a number of enzymes. The major steps involved in $\mathrm{BC}$ biogenesis are, phosphorylation of glucose to glucose-6-phosphate, isomerization of glucose6-phosphate to glucose-1-phosphate,transition of glucose-1-phosphate to uridine diphosphate glucose (UDPG) and integration of linear $\beta 1,4$-glucan chains from UDPG. Reactions are catalysed by glucokinase, phosphoglucomutase, UDPG pyrophosphorylase, cellulose synthase respectively. Finally, polymerised subunits ( $\beta 1$, 4-glucan chains) crystallized into $B C^{5}$.

Bacterial cellulose is produced mainly by Gram-negative non-pathogenic and free-living bacterial species such as Acetobacter, Salmonella, Rhizobium, Alcaligens, Agrobacterium, and Pseudomonas also by Sarcina ventriculi, a grampositive bacteria species. Among all these groups of bacteria, the most potent producer belongs to the genus Komagataeibacter (initially classified as Acetobacter $s p)^{6,7}$. Komagataeibacter belongs to acetic acid bacteria (AAB). The different members belong to this genus such as Komagataeibacter medellinensis, Komagataeibacter xylinus, Komagataeibacter nataicola, Komagataeibacter saccharivorans, Komagataeibacter oboediens, Komagataeibacter rhaeticus, Komagataeibacter hansenii, and Komagataeibacter pomacetiare wellknown producer of bacterial cellulose ${ }^{4,8}$. Among the members, Komagataeibacter xylinus forms the model organism for $\mathrm{BC}$ biogenesis. The members of the genus Komagataeibacter are obligate aerobic, gram-negative, and rod-shaped nonmotile organisms, they are positive for catalase and negative for oxidase and can oxidise ethanol to acetic acid8.

Investigations on the bacterial extracellular gelatinous fiber led to the discovery of BC by A.J Brown in 1886. He first reported that the white gelatinous pellicle present on the static culture medium is bacterial cellulose $e^{6,9,10}$. During biosynthesis, BC molecules are first synthesized intracellular and subsequently secreted via squeezing pores on the longitudinal axis of the bacterial cell's outer membrane. Normally the secreted BC measures about $100 \mathrm{~nm}$ in width and around $100 \mathrm{~mm}$ in length. Microbial cellulose forms as an aggregate of nano fibrils of 2-4 nm width. These nanofibers are stabilized by inter and intermolecular Hydrogen bond ${ }^{5}$. Bacterial cellulose is mainly a combination of cellulose I and cellulose $\|^{9,10}$.

The absence of lignin and hemicellulose makes the purity level of $B C$ very high. The purification and isolation process of $B C$ is comparatively effortless than that of plant cellulose, making $B C$ a favorite biopolymer ${ }^{11}$. It exhibits tremendous physicochemical properties such as high mechanical strength, high water holding capacity, biocompatibility, and high purity raw material in wide-ranging areas like biomedical, food, agriculture, paper, textile industries, and electronics ${ }^{6,9,11}$. Applications of microbial cellulose can be further enhanced by recent techniques such as nanofications and functionalization of BC. Thus, the aim of this review is to discuss various aspects of $B C$ production including different methods of bacterial isolation and also the major application strategies of BC.

\section{Production of Bacterial cellulose}

For the systematic production of bacterial cellulose, the prime need is an efficient and stable bacterial strain, which should have cheap growth requirements and also the ability to maintain effortlessly $y^{6}$. Fabrication of different $\mathrm{BC}$ shapes like sheets, pellicle, granules, gels, and films can be achieved by manipulating the culture conditions ${ }^{11}$. Previous studies showed Acetobacter sp can be isolated from natural sources. The various sources of Acetobacter sp include fruits ${ }^{12}$, vinegar ${ }^{13}$, agricultural waste ${ }^{14}$, and industrial by-products ${ }^{15}$.

\section{Culture media for Acetobacter Sp}

Components of the growth medium, 
environmental conditions, accumulation of metabolic by-products may affect bacterial cellulose production; therefore ideal designing of the culture medium is essential for optimum bacterial growth and cellulose production ${ }^{10}$.

Past studies showed that Hestrin Schramm (HS) medium is the best known synthetic complex medium for the isolation of Acetobacter $\mathrm{sp}^{6,16-19}$. A study by Dubey et $a l^{16}$ reported that modification of HS media with hot water-sweet lime extract can improve BC production. Modified forms of HS medium and Yamanaka medium were used in another study by Krystynowicz et $a /^{17}$.

Molina et $a l^{18}$ discussed the usage of alternative energy sources (AES) along with conventional growth mediums like ethanol, acetic acid, lactic acid, sodium citrate, amino acid, and vitamin $C$ to improve bacterial yield and cellulose production.

Another study conducted by Mohammadkazemi et $a l^{19}$ explained the comparative production of $\mathrm{BC}$ by Acetobacter xylinus in three different media. The media used were Hestrin Schramm (HS) and Yamanaka, Zhou, and he found out that more bacterial cellulose production was on the first two media and a decreased production in the third medium. The study also concluded that the combination of nitrogen and carbon sources was very effective for BC synthesis.

Ruka et $a^{20}$ published a study in which they investigated the effect of different carbon sources on the $\mathrm{BC}$ yield by modifying the media. The four media used were Hestrin Schramm (HS), Yamanaka, Zhou, and CSL (corn steep liquor).
Media added with glucose, mannitol and sucrose showed improved bacterial cellulose yield. A study done by Kouda et $a^{21}$ mentioned the modified use of CSL medium with fructose, results showed improved BC production. Various parameters which affect the bioprocess are mainly, $\mathrm{pH}$, temperature, agitation, and the level of dissolved oxygen, optimization of all these parameters are the key factor for bacterial cellulose production ${ }^{22-25}$. Gorgieva et $a l^{4}$ reported that the highest yield of BC can be achieved by modifying HS media by substituting the glucose with mannitol, sucrose, or galactose. Wang et $a^{26}$ observed that fructose can improve BC production when compared to other carbon sources. The composition of the different culture media is presented in Table 1.

Table 1. Different types of culture media and their composition

\begin{tabular}{lccc}
\hline Composition & \multicolumn{3}{c}{ Media } \\
\cline { 2 - 4 } & $\begin{array}{c}\text { Hestrin } \\
\text { Schramm } \\
\text { (HS) }\end{array}$ & $\begin{array}{c}\text { Yamanaka } \\
(\mathrm{Y})\end{array}$ & $\begin{array}{c}\text { Zhou } \\
(\mathrm{Z})\end{array}$ \\
\hline Glucose & $\checkmark$ & $\checkmark$ & $\checkmark$ \\
Corn-steep liquor & - & - & $\checkmark$ \\
Yeast-extract & $\checkmark$ & $\checkmark$ & - \\
Peptone & $\checkmark$ & - & - \\
$\mathrm{Na}_{2} \mathrm{HPO}_{4}$ & $\checkmark$ & - & - \\
$\mathrm{Citric} \mathrm{acid.} \mathrm{Water}$ & $\checkmark$ & - & - \\
$\left(\mathrm{NH}_{4}\right)_{\mathrm{SO}}$ & - & $\checkmark$ & $\checkmark$ \\
$\mathrm{KH}_{2} \mathrm{PO}_{4}$ & - & $\checkmark$ & $\checkmark$ \\
$\mathrm{MgSO}_{4} \cdot 7 \mathrm{H}_{2} \mathrm{O}$ & - & $\checkmark$ & $\checkmark$ \\
\hline
\end{tabular}

$\checkmark=$ item present in the media, $-=$ item absent in the media

Table 2. Alternate medium used for the enumeration of Acetobacter $\mathrm{sp}$

\begin{tabular}{|c|c|c|}
\hline Media type & Features & Reference \\
\hline $\begin{array}{l}\text { Plant Extract } \\
\text { (Common tea, unroasted } \\
\text { Coffee, cacao) }\end{array}$ & Stimulating effect of Xanthine & 28 \\
\hline $\begin{array}{l}\text { Beverage industrial waste } \\
\text { (Citrus peel and Pomace } \\
\text { Enzymolysis) }\end{array}$ & $\begin{array}{l}\text { Enzyme treatment increases } \\
\text { the reducing sugar content }\end{array}$ & 27 \\
\hline Wheat straw acid hydrolysate & Wheat straw acid hydrolysate & 29 \\
\hline Tomato juice & higher carbon level & 30 \\
\hline $\begin{array}{l}\text { Water melon and mandarin } \\
\text { juice }\end{array}$ & $\begin{array}{l}\text { increased level of carbon and } \\
\text { Nitrogen }\end{array}$ & 31 \\
\hline Litchi extract & higher crystallinity & 32 \\
\hline
\end{tabular}




\section{Alternate media for Acetobacter Sp isolation}

Past studies proved that the role of alternate media with complex organic constituents is more productive and profitable than the traditional synthetic defined medium. The use of agricultural and industrial scrap as a growth medium is not only economical but also an eco-friendly waste management system ${ }^{27}$. The alternate medium used for the enumeration of Acetobacter $\mathrm{sp}$ is shown in Table 2.

\section{Use of additives for $\mathrm{BC}$ production}

Incorporation of various chemicals in $\mathrm{BC}$ culture medium can improve the production of bacterial cellulose in both static and submerged cultures. Past studies showed that Carboxymethyl cellulose $(\mathrm{CMC})$ is a better additive to improve bacterial cellulose production. CMC is watersoluble cellulose with a carboxymethyl group. It helps in the prevention of large BC aggregates formation and enhances its solubility ${ }^{33-36}$. Incorporation of CMC in culture medium keeps the $\mathrm{BC}$ fibers thin and turns it more suitable for its special applications.

Ishida et $\left.a\right|^{37}$ mentioned that the effect of water-soluble polysaccharides such as agar can improve bacterial cellulose production by enhancing the viscosity of the culture medium. The addition of agar in the medium may promote the dispersion of pellets and thus prevents their aggregation and maximize BC production. Bae et $a f^{\beta 8}$ also viewed the yield of bacterial cellulose is improving with the effect of agar.

BC nanofibers are an excellent candidate for drug delivery systems; experiments conducted by Beekman et $a^{\beta 9}$ have proved that the addition of Poly Ethylene Glycol (PEG) to the culture medium modifies the BC fibers with increased transparency, loading capacity, and also the effective drug delivery properties.

In a study conducted by Zhou et $a 1^{40}$ observed that sodium alginate, a water-soluble polysaccharide can promote bacterial cellulose production by hindering the formation of large BC production.

\section{Cultivation techniques}

Since bacterial cellulose is a biopolymer with extensive applications its efficient and costeffective production is of utmost importance. Soon after the discovery of this material intense investigations have been progressing for the same. Several techniques were proposed out of which some are possible methods for economic, and commercial tools for bacterial cellulose production $^{17,41}$. Static cultivation, agitated /shaking cultivation, and airlift reactors are currently using fermentation techniques for better BC yield. However, researchers are trying to develop new reactors for improved $B C$ production. Large scale production for the commercial application requires $B C$ with optimum shape, composition and maximum $B C$ properties ${ }^{17,42,43}$. BC secretes as a pellicle under shaking condition or as a sheet at air-liquid interface in static culture ${ }^{41,44-46}$. Advanced techniques for the fabrication of biomolecules using microbial cellulose are in progress and the cell-free system is one such technique ${ }^{47,48}$.

\section{Static cultivation technique for BC production}

Frequently applied method for the production of bacterial cellulose, is a relatively simple method for lab-scale production of $B C$. Broth medium is filled in shallow containers or trays used for cultivation, incubated up to 5-14 days at optimum temperature $\left(28-30^{\circ} \mathrm{C}\right)$ and $\mathrm{pH}$. The thick pellicle formed on the vacuum/liquid interface is directly related to the surface area. Here, the time of incubation is the main factor that controls the thickness of BC. Decreased productivity and increased cultivation time limit industrial application of this culture technique. Pellicle formation is influenced by the surface of the culture medium, and also aeration at the vacuum/liquid interface will yield high-quality cellulose $44,49,50$. A newly invented bioreactor system, Horizontal Lift Reactor (HoLiR) was developed for semi-continuous production of BC. This system offers the benefits of both static and continuous cultivation techniques in a costeffective manner ${ }^{50}$.

\section{Submerged/Agitated cultivation technique for BC production}

The two chief drawbacks of static culture are high cost and low rate of production. To minimize these issues researchers suggested the submerged/agitated technique. The basic concept behind this culture technique was to optimize the oxygen supply to the growing bacteria, rotating speed, culture time, and additive types used in the culture medium, are the factors which contribute to the size and shape of the $\mathrm{BC}^{50}$. In this method, maximum yield in comparatively 
less time can be possible. The higher yield of $B C$ is possibly due to the homogeneous distribution of nutrients, cells, air, and substrates ${ }^{44,51,52}$. In agitating cultivation method cells have improved contact with circulating air leads to an improved growth rate ${ }^{44}$.Previous studies showed that the $B C$ yield from the agitated technique is lower when compared to the static method, probably due to the emergence of cellulose mutant strains under agitated technique ${ }^{6,50,53}$ which may lower the $B C$ yield. Even though there are drawbacks like instability of bacterial strain, high shear force, asymmetrical shape of the produced BC, and the accumulation of BC mutants, some research has suggested that the submerged (agitated) culture method is ideal for large scale production ${ }^{44,50}$.

\section{Purification and Characterisation of Bacterial Cellulose}

Many studies have shown that the method employed for the purification of harvested bacterial cellulose was treated with sodium hydroxide. Characterization of bacterial cellulose was done by Scanning electron microscope
(SEM). A study conducted by Rangaswami et $a 1^{54}$ concluded that the bacterial cellulose fibers are made of a random assembly of nano fibrils with the aid of SEM, these findings are parallel with many other studies ${ }^{15,54,55}$. The crystalline structure of harvested bacterial cellulose can be examined by X-ray diffraction study ${ }^{14,34}$. The thermal degradation behavior of the harvested $B C$ can be assessed by thermogravimetric analysis (TGA ${ }^{15}$.

\section{Bacterial Cellulose-Applications}

Microbial cellulose, a biopolymer with distinctive attributes such as high durability, biodegradability, and high-water holding capacity has made it a demanding product in the field of biotechnology with a number of applications $s^{56,57}$. Moldability of BC at the time of culture has crucial features that impart an extended application to BC. The major applications are summarised in the following discussions and Fig. 1.

\section{Bacterial Cellulose Composites}

Fascinating structural and physiological features of BC turn it into an absolute tool for several applications. Particularly the nanofibrillar

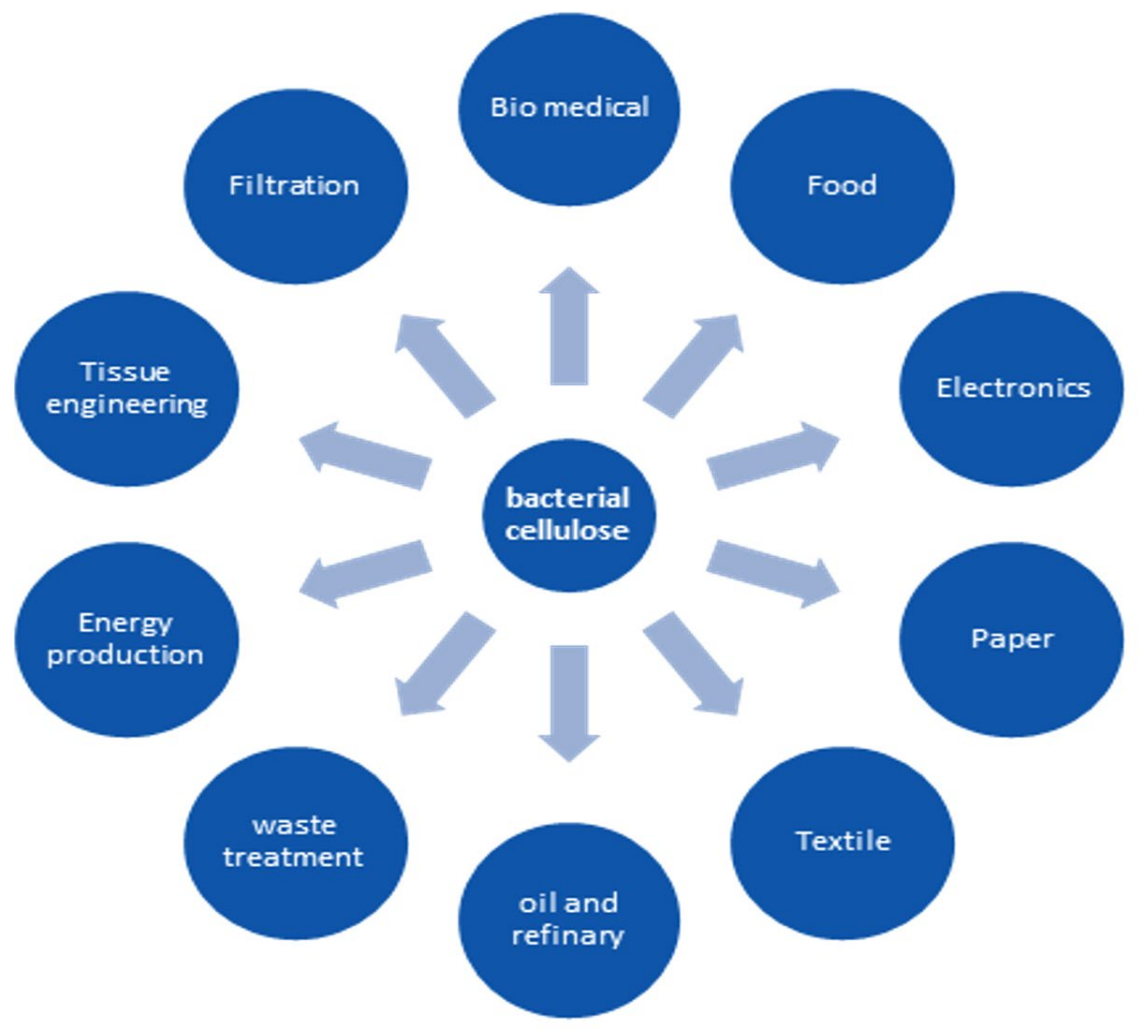

Fig. 1. Applications of bacterial cellulose 
structure of BC turns it into an ideal for composites fabrication. In spite of all the features, BC has some limitations like lack of antibacterial activity and antioxidant properties which limit its acceptability in the medical field. Moreover, BC does not have properties such as electrical conductivity, optical transparency, and hydrophobicity which limit its use in electronic industries. Pure BC is not suitable for direct use in electrical devices, batteries, sensors, and electromagnetic shielding. To overcome these constraints and also to extend its application, scientists have developed various $\mathrm{BC}$ composites. $\mathrm{BC}$ is ideal to use as a reinforcing and matrix material for composite design.

$B C$ composite fabrication requires a series of synthetic procedures; a vast number of nanomaterial's ( $\mathrm{Au}, \mathrm{Ag}, \mathrm{ZnO}$, etc.) and polymers (chitosan, $P E G$, etc.) are involved in composite making. All this turns pure BC with additional properties such as antibacterial activity conductivity and transparency; Current advances in this field are the development of fuel cells made

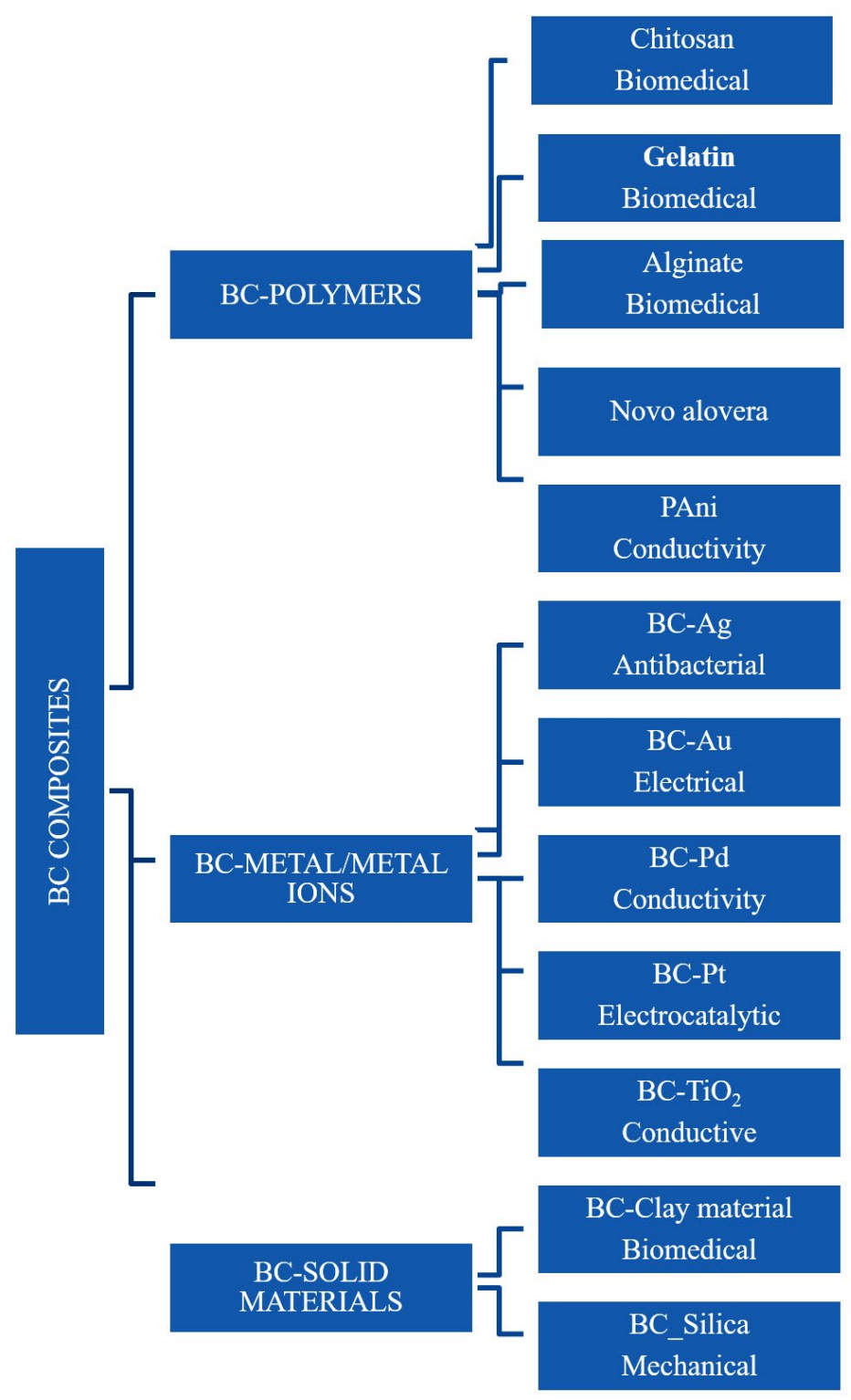

Fig. 2. Classes of $B C$ Composites and their Functions 
of BC composites, fabricating display devices, and synthetic organs. Further comprehensive studies in this field are a necessity into develop novel BC composites to meet new applications in assorted areas $^{43,44,58}$. Various classes of BC composites and their applications are shown in Fig. 2.

\section{Biomedical Applications of BC}

BC composed of randomly distributed microfibrillar networks with unique structural properties, bio absorbency, high water holding capacity, gaseous exchange property, high-level of crystallinity, biodegradability is highlighted features of bacterial cellulose for use in the biomedical field. It forms a compatible material with a nontoxic, non-pyrogenic nature ${ }^{4,56}$. The basic limitations of $\mathrm{BC}$ as a biomedical tool are its inability to trigger initial cell adhesion, very slow degradation capacity, etc. It can be eliminated by chemical and physical modifications of prepared BC. In-situ (done by alteration of culture media, carbon source, and use of additives) and ex- situ (performed by chemical and physical treatments of $B C$ yield) methods are used in $B C$ modification ${ }^{4}$. Cellulose digesting enzymes such as cellulase and beta glucanases are absent in human beings moreover BC is poorly soluble in various physiological media and turns it into a potential constituent of various biomaterials with attractive features. Lack of both antibacterial and antioxidant properties limits its use in the medical field. Fabrication of various BC composites helps to overcome this. Modifications during the fermentation process helps to mold BC into any form, size or thickness and thus it can be specifically fit for varied applications ${ }^{59}$. Fig. 3 shows examples of biomedical applications of bacterial cellulose.

\section{Food Applications of BC}

The consumption of bacterial cellulose originated long back, the fermented food product Nata de coco (prepared from coconut water and bacteria) has been popularized in the Philippines from $1973^{9}$. A number of studies reported that consumption of $B C$ does not cause any type of toxicity to humans ${ }^{60}$ and also studies proved the safety side of $B C$ as a food material. Therefore, BC has been classified as generally recognised as safe (GRAS) by the US Food and Drug Administration since 1992. The incorporation of bacterial cellulose to various food items can improve their quality and

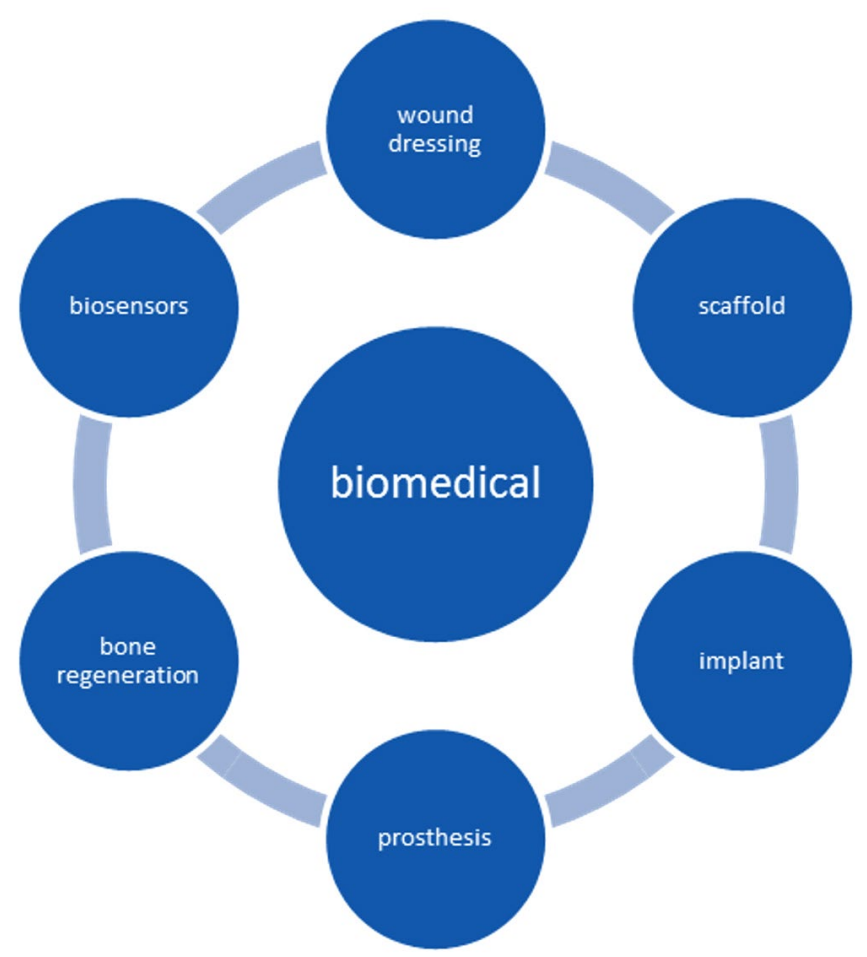

Fig. 3. Bio medical applications of bacterial cellulose 
character. Attractive suspending, water retention, thickening, emulsifying and stability properties turn $B C$ into a recommended candidate in the food industry. Yang et $a /^{53}$ reported that addition of $B C$ in pasty food can upgrade firmness and better texture. The addition of $B C$ in meat food items can improve its juiciness and chewiness due to its ability to maintain humidity ${ }^{60}$. BC has great potential in the food packaging industries because it is compatible with the number of food items ${ }^{60,4}$. Various food applications of $B C$ are listed in Table 3.

Table 3. Food applications of bacterial cellulose

\begin{tabular}{ll}
\hline Applications & Ref. \\
\hline $\begin{array}{l}\text { Use as thickening agent, Low calorie } \\
\text { desert, fabricated food, stabilizer, }\end{array}$ & $49,56,61$ \\
$\begin{array}{l}\text { Texture modifier, salads } \\
\text { Cell immobilization agent in wine }\end{array}$ & 56,62 \\
$\begin{array}{l}\text { production } \\
\text { In vitro fermentation of plant dietary fibre }\end{array}$ & 56,63 \\
Food packaging & $56,60,64$ \\
\hline
\end{tabular}

\section{Other Applications}

BC can be successfully used in the field of electronics ${ }^{55,56}$ like the manufacturing of speaker diaphragm ${ }^{65}$. The Shape retention ability of bacterial cellulose is the main property used for this purpose. Sony corps developed loudspeakers and diaphragm with bacterial cellulose $\mathrm{e}^{56,66}$. Recent studies also disclosed the perspective of nano cellulose fibres for the manufacture of organic light emitting diode (OLED) $)^{56,67,68}$.

Previous studies observed that high quality paper can be prepared from bacterial cellulose pellets from agitated culture. Mixing of paper pulp with crushed bacterial cellulose can also be used as a method of preparing the paper with high tensile strength ${ }^{69-71}$. Specialized paper with high kaolin retention and fire resistance can be achieved by the addition of modified $\mathrm{BC}^{70}$. A variety of $\mathrm{BC}$ composites are also used for the paper manufacturing industry ${ }^{71}$.

Studies proved that bacterial cellulose is a promising biopolymer in the textile industry mainly because of its high unit tensile strength. It is the spectacular feature of bacterial cellulose to be used in the synthesis of geotextiles ${ }^{55,72}$. Chan et $a l^{73}$ also discussed novel applications of bacterial cellulose in the textile industry.

Hassan et $a l^{74}$ tested that high-efficiency membrane filters can be prepared from BC. These membranes can be effectively used in oil refineries for separating oil from stabilized or non-stabilized oil in water emulsions. Galdino et $a 7^{75}$ developed bacterial cellulose membrane filters for the treatment of oil filters, and achieved a $100 \%$ oil removal technique from all emulsions. Other studies also discussed the use of bacterial cellulose composites as an efficient filtration membranaes ${ }^{76}$.

Recently, bacterial cellulose composites have been successfully used in the treatment of waste water from the food industry, pharmaceutical and oil fields. Graphene oxide and bacterial cellulose composites exhibit good permeability to different organic or inorganic ions particularly in nano-scale from angstrom-scale ${ }^{77}$. Novel BC membrane composite is another attraction of $B C$ for water treatment plants ${ }^{78,79}$.

Bacterial cellulose nanofibers have unique properties to transform into nanosized materials with optical, electrical, and magnetic properties ${ }^{80-82}$. BC electronic applications include fabrication of piezoelectric material for different engineering applications, Photoluminescent nano paper optical sensor etc ${ }^{83,84}$. Various features of bacterial cellulose make it an excellent tool in tissue engineering. Modification of bacterial cellulose for tissue engineering use can be done by in-situ or ex situ methods ${ }^{84}$.

\section{CONCLUSION}

As a biopolymer with fascinating features bacterial cellulose is real material with wide applications. It can replace plant cellulose with many advantages. The unique physicochemical properties of bacterial cellulose mainly include biocompatibility, high moldability and tensile strength, high water retention capacity. Basically, microbial cellulose can be obtained from a number of renewable sources, the Acetobacter sp is the role model for bacterial cellulose biogenesis. This review is primarily focusing on the synthesis of cellulose by Acetobacter sp. Different sources for Acetobacter sp isolation and various culture media or their alternatives and cultural techniques have been updated in this review. To meet the elevated 
demand for bacterial cellulose, a strong, feasible method should be employed. Extensive studies on biochemical and genetic features of Acetobacter $\mathrm{sp}$ are required to be performed in order to understand and improve the cellulose biogenesis within the same.

\section{ACKNOWLEDGMENTS}

The authors are sincerely thankful to the management of Karpagam Academy of Higher Education Coimbatore-641021, Tamil Nadu, India for their constant support and encouragement.

\section{CONFLICT OF INTEREST}

The authors declare that there is no conflict of interest.

\section{AUTHORS' CONTRIBUTION}

All authors listed have made a substantial, direct and intellectual contribution to the work, and approved it for publication.

\section{FUNDING}

None.

\section{DATA AVAILABILITY}

All datasets generated during this study are included in the manuscript.

\section{ETHICS STATEMENT}

Not applicable.

\section{REFERENCES}

1. Cannon RE, Anderson SM. Biogenesis of bacterial cellulose. Crit Rev Microbiol. 1991;17(6):435-447. doi: 10.3109/10408419109115207

2. Portela R, Leal CR, Almeida PL, Sobral RG. Bacterial cellulose: a versatile biopolymer for wound dressing applications. Microb Biotechnol. 2019; 12(4):586-610. doi:10.1111/1751-7915.13392

3. Toyosaki H, Naritomi T, Seto A, Matsuoka M, Tsuchida T, Yoshinaga F. Screening of bacterial cellulose producing Acetobacter strains suitable for agitated culture. Biosci Biotechno Biochem. 1995;59(8):1498-1502. doi: 10.1271/bbb.59.1498

4. Gorgieva S, Trček J. Bacterial Cellulose: Production, Modification and Perspectives in Biomedical Applications. Nanomaterials (Basel). 2019;9(10):1352. Published 2019. doi :10.3390/nano9101352

5. Wei L, Haishun D, Miamio Z, et al. Bacterial cellulosebased composite scaffolds for biomedical applications: a review. ACS Sustain Chem Eng. 2020;8(20):75367562. doi: 10.1021/acssuschemeng.0c00125

6. Prashant RC, Iswar BB, Shrikant AS, Rekha SS. Microbial cellulose: Fermentative production and applications. Food Technol Biotechnol. 2009;47(2):107-124.

7. Gomes RJ, Borges MF, Rosa MF, et al. Acetic Acid Bacteria in the Food Industry: Systematics, Characteristics and Applications. Food Techno Biotechnol. 2018;56(2):139-151. doi:10.17113/ ftb.56.02.18.5593

8. Jure S,Ilse C, Peter V, Fanedlc L, Trcekad J. Genome sequences and description of novel exopolysaccharides producing species Komagataeibacter pomaceti sp. nov and reclassification of Komagataeibacter kombuchae (Dutta and Gachhui 2007) Yamada et al., 2013 as a later heterotypic synonym of Komagataeibacter hansenii (Gossele et al. 1983) Yamada et al., 2013. Syst Appl Microbiol. 2018;41(6):581-592. doi: 10.1016/j. syapm.2018.08.006

9. Blanco Parte FG, Santoso SP, Chou CC, et al. Current progress on the production, modification, and applications of bacterial cellulose. Crit Rev Biotechnol. 2020; 40(3):397-414. doi:10.1080/07388551.2020.17 13721

10. AJ, B. XLIII.-On an acetic ferment which forms cellulose. J Chem Soc Trans. 1986;49:432-439.doi: 10.1039/ CT8864900432

11. Niloofar E, Amin M, Nafiseh M. Zandi N, Simchi A. Processing and properties of Nano fibrous bacterial cellulose-containing polymer composites: a review of recent advances for biomedical applications. Polym Rev. 2020;60(1):144-170. doi: 10.1080/15583724.2019.1663210

12. lino $T$, Suzuki $R$, Kosako $Y$, Ohkuma M, Komagata K, Uchimura T. Acetobacter okinawensis sp. nov., Acetobacter papayae sp. nov., and Acetobacter persicus sp. nov.; novel acetic acid bacteria isolated from stems of sugarcane, fruits, and a flower in Japan. J Gen Appl Microbiol. 2012;58(3):235-243. doi:10.2323/ jgam.58.235

13. Janja T, Jana R, Peter. Phenotypic characterization and RAPD-PCR profiling of Acetobacter sp. isolated from spirit vinegar production. Food Technol Biotechnol. 1997;35(1):63-67.

14. Ye J, Zheng S, Zhang Z, et al. Bacterial cellulose production by Acetobacter xylinum ATCC 23767 using tobacco waste extract as culture medium. Bioresour Technol. 2019; 274:518-524. doi:10.1016/j. biortech.2018.12.028

15. Jahan F, Kumar V, Saxena RK. Distillery effluent as a potential medium for bacterial cellulose production: A biopolymer of great commercial importance. Bioresour Technol. 2018;250:922-926. doi:10.1016/j. biortech.2017.09.094

16. Dubey S, Singh J, Singh RP. Biotransformation of sweet lime pulp waste into high-quality nanocellulose with an excellent productivity using Komagataeibacter europaeus SGP37 under static intermittent fed-batch cultivation. Bioresour Technol. 2018;247:73-80. doi:10.1016/j.biortech.2017.09.089

17. Krystynowicz A, Czaja W, Wiktorowska-Jezierska A, Gonçalves-Miśkiewicz M, Turkiewicz M, Bielecki S. Factors affecting the yield and properties of bacterial cellulose. J Ind Microbiol Biotechnol. 2002;29(4):189195. doi: 10.1038/sj.jim.7000303 
18. Molina-Ramírez C, Enciso C, Torres-Taborda M, et al. Effects of alternative energy sources on bacterial cellulose characteristics produced by Komagataeibacter medellinensis. Int J Biol Macromol. 2018; 117:735-741. doi:10.1016/j.ijbiomac.2018.05.195

19. Mohammadkazemi F, Azin M, Ashori A. Production of bacterial cellulose using different carbon sources and culture media. Carbohydr Polym. 2015;117:518-523. doi:10.1016/j.carbpol.2014.10.008

20. Ruka DR, Simon GP, Dean KM. Altering the growth conditions of Gluconacetobacter xylinus to maximize the yield of bacterial cellulose. Carbohydr Polym. 2012;89(2):613-622. doi:10.1016/j. carbpol.2012.03.059

21. Tohru K, Hisato Y, Fumihiro Y. Effect of agitator configuration on bacterial cellulose productivity in aerated and agitated culture. J Ferment Bioeng. 1997;83(4):371-376. doi: 10.1016/S0922338X(97)80144-4

22. Kim YJ, Kim JN, Wee YJ, Park DH, Ryu HW. Bacterial cellulose production by Gluconacetobacter sp. PKY5 in a rotary biofilm contactor. App/ Biochem Biotechnol. 2007;137-140(1-12):529-537. doi:10.1007/s12010007-9077-8

23. Verschuren PG, Cardona TD, Nout MJ, et al. Location and limitation of cellulose production by Acetobacter xylinum established from oxygen profiles. J Biosci Bioeng. 2000;89(5):414-419. doi: 10.1016/s13891723(00)89089-1

24. Bae S, Shoda M. Statistical optimization of culture conditions for bacterial cellulose production using BoxBehnken design. Biotechnol Bioeng. 2005;90(1):20-28. doi:10.1002/bit.20325

25. Hwang JW, Yang YK, Hwang JK, Pyun YR, Kim YS. Effects of $\mathrm{pH}$ and dissolved oxygen on cellulose production by Acetobacter xylinum BRC5 in agitated culture. J Biosci Bioeng. 1999;88(2):183-188. doi: 10.1016/s13891723(99)80199-6

26. Wang SS, Han YH, Chen JL, et al. Insights into Bacterial Cellulose Biosynthesis from Different Carbon Sources and the Associated Biochemical Transformation Pathways in Komagataeibacter sp. W1. Polymers (Basel). 2018;10(9):963. Published 2018 Aug 31. doi:10.3390/polym10090963

27. Fan X, Gao Y, He W, et al. Production of nano bacterial cellulose from beverage industrial waste of citrus peel and pomace using Komagataeibacter xylinus. Carbohydr Polym. 2016;151:1068-1072. doi:10.1016/j. carbpol.2016.06.062

28. Fontana JD, Franco VC, de Souza SJ, Lyra IN, de Souza AM. Nature of plant stimulators in the production of Acetobacter xylinum ("tea fungus") biofilm used in skin therapy. Appl Biochem Biotechnol. 1991;28:341-351. doi: 10.1007/bf02922613

29. Hong F, Zhu YX, Yang G, Yang XX. Wheat straw acid hydrolysate as apotential cost-effective feedstock for production of bacterial cellulose. J Chem Technol Biotechnol. 2011;86(5):675-680. doi: 10.1002/ jctb. 2567

30. Kosseva MR, Li M, Zhang J, He Y, Tjutju NAS. Study on bacterial cellulose production from fruit juices. $2^{\text {nd }}$ International Conference on Bioscience and
Biotechnology. 2017;2(1):36-42.doi: 10.17501/ biotech.2017.2104

31. Kumar V, Sharma DK, Bansal V, Mehta D, Sangwan RS, Yadav SK. Efficient and economic process for the production of bacterial cellulose from isolated strain of Acetobacter pasteurianus of RSV-4 bacterium. Bioresour Technol. 2019;275:430-433. doi:10.1016/j. biortech.2018.12.042

32. Yang $\mathrm{XY}$, Huang $\mathrm{C}, \mathrm{Guo} \mathrm{HJ}$, et al. Bacterial cellulose production from the litchi extract by Gluconacetobacter xylinus. Prep Biochem Biotechnol. 2016;46(1):39-43. doi:10.1080/10826068.2014.958163

33. Asako $\mathrm{H}$, Masaki T, Hirouki $\mathrm{Y}$, Fumitaka H. In situ crystallization of bacterial cellulose III. Influences of different, polymeric additives on the formation of microfibrils as revealed by transmissionelectron microscopy.Cellulose. 1998;5(3):201-213. doi: 10.1023/A:1009233323237

34. Kuan CC, Jeffery MC, Ali D. Effect of different additives on bacterial cellulose production by Acetobacter xylinum and analysis of material property. Cellulose. 2009;16(6):1033-1045. doi: 10.1007/s10570-0099346-5

35. Haigler $\mathrm{CH}$, White AR, Brown RM Jr, Cooper KM. Alteration of in vivo cellulose ribbon assembly by carboxymethyl cellulose and other cellulose derivatives. J Cell Biol. 1982; 94(1):64-69. doi: 10.1083/ jcb.94.1.64

36. Marit S, Stephanie H, Vasken K, Dieter K. Controlling the water content of never dried and reswollen bacterial cellulose by the addition of water-soluble polymers to the culture medium. J Polym Sci Pol Chem. 2004;42(3):463-470. doi: 10.1002/pola.10862

37. Ishida T, Mitarai M, Sugano Y, Shoda M. Role of water-soluble polysaccharides in bacterial cellulose production. Biotechnol Bioeng. 2003;83(4):474-478. doi:10.1002/bit.10690

38. Bae S, Sugano Y, Shoda M. Improvement of bacterial cellulose production by addition of agar in a jar fermentor. J Biosci Bioeng. 2004;97(1):33-38. doi:10.1016/S1389-1723(04)70162-0

39. Beekmann U, Schmölz L, Lorkowski S, et al. Process control and scale-up of modified bacterial cellulose production for tailor-made anti-inflammatory drug delivery systems. Carbohydr Polym. 2020;236:116062. doi:10.1016/j.carbpol.2020.116062

40. Zhou LL, Sun DP, Hu LY, Li YW, Yang JZ. Effect of addition of sodium alginate on bacterial cellulose production by Acetobacter xylinum. J Ind Microbiol Biotechnol. 2007;34(7):483-489.doi: 10.1007/s10295-007-0218-4

41. Islam MU, Ullah MW, Khan S, Shah N, Park JK. Strategies for cost-effective and enhanced production of bacterial cellulose. Int J Biol Macromol. 2017;102:1166-1173. doi:10.1016/j.ijbiomac.2017.04.110

42. Seung HM, Ji M, Hwa YC, Seong JK. Comparisons of physical properties of bacterial cellulose produced in different culture conditions using saccharified food wastes. Biotechnol Bioprocess Eng. 2006;11(1):26-31. doi: $10.1007 \% 2 F B F 02931864$

43. Cristina C, Ana B, Angeles B, Carlos N. Enhancement of the fermentation process and properties of bacterial cellulose: a review. Cellulose. 2016;23(1):57-91. doi: 
$10.1007 /$ s10570-015-0802-0

44. UI-Islam M, Khan S, Khattak WA, Ullah MW, Park JK. Synthesis, chemistry, and medical applicationof bacterial cellulose nanocomposites. Eco-friendly Polymer Nanocomposites (Springer). 2015;399-437. doi: 10.1007/978-81-322-2473-0_13

45. Ullah MW, Khattak WA, UI-Islam M, Khan S, Park JK. Metabolic engineering of synthetic cell-free systems: strategies and applications. Biochem Eng J. 2016;105,391-405. doi: 10.1016/j.bej.2015.10.023

46. Omer S, Salman K, Taousk K, Joong K. Physicochemical and mechanical characterization of bacterial cellulose produced with an excellent productivity in static conditions using a simple fed-batch cultivation strategy. Carbohydr Polym. 2010; 82(1):173-180. doi: 10.1016/j.carbpol.2010.04.052

47. Khattak WA, Ullah MW, UI-Islam M, et al. Developmental strategies and regulation of cell-free enzyme system for ethanol production: a molecular prospective. Appl Microbiol Biotechnol. 2014; 98(23):9561-9578. doi:10.1007/s00253-014-6154-0

48. Kralisch D, Hessler N, Klemm D, Erdmann R, Schmidt W. White biotechnology for cellulose manufacturing--the HoLiR concept. Biotechnol Bioeng. 2010; 105(4):740747. doi:10.1002/bit.22579

49. Atsushi O, Hideyuki S, Hideo K, Shigeru Y. Bacterial cellulose I. Two-stage fermentation process for cellulose production by Acetobacter aceti. Food Hydrocoll. 1992;6(5):471-477. doi: 10.1016/S0268005X(09)80032-5

50. Wang J, Tavakoli J, Tang Y. Bacterial cellulose production, properties and applications with different culture methods - A review. Carbohydr Polym. 2019; 219:63-76. doi:10.1016/j.carbpol.2019.05.008

51. Hu Y, Catchmark JM. Formation and characterization of sphere like bacterial cellulose particles produced by Acetobacter xylinum JCM 9730 strain. Biomacromolecules. 2010;11(7):1727-1734. doi: 10.1021/bm100060v

52. Ha JH, Shah N, UI-Islam M, Khan T, Park JK. Bacterial cellulose production from a single sugar $\alpha$-linked glucuronic acid-based oligosaccharide. Process Biochem. 2011;46(9):1717-1723. doi: 10.1016/j. procbio.2011.05.024

53. Huang Y, Zhu C, Yang J, Nie Y, Chen C, Sun D. Recent advances in bacterial cellulose. Cellulose. 2014;21(1):130. doi: 10.1007/s10570-013-0088-z

54. Rangaswamy BE, Vanitha KP, Hungund BS. Microbial cellulose production from bacteria isolated from rotten fruit. Int J Polym Sci. 2015;2015:280784. doi: 10.1155/2015/280784

55. Andrea FD, Maria AV, Leonie AS. Bacterial cellulose: an ecofriendly biotextile. Int $J$ of Textile and Fashion Technol. 2017;7(1):11-26.

56. Lin SP, Calvar IL, Catchmark JM, Liu JR, Demirci A, Cheng KC. Biosynthesis, production and applications of bacterial cellulose.Cellulose. 2013;20(5):2191-2219. doi: 10.1007/s10570-013-9994-3

57. Czaja WK, Young DJ, Kawecki M, Brown RM Jr. The future prospects of microbial cellulose in biomedical applications. Biomacromolecules. 2007;8(1):1-12. doi: 10.1021/bm060620d
58. Shah N, Ul-Islam M, Khattak WA, Park JK. Overview of bacterial cellulose composites: a multipurpose advanced material. Carbohydr Polym. 2013; 98(2):1585-1598. doi:10.1016/j.carbpol.2013.08.018

59. Picheth GF, Pirich $\mathrm{CL}$, Sierakowski MR, et al. Bacterial cellulose in biomedical applications: A review. Int J Biol Macromol. 2017; 104(Pt A):97-106. doi:10.1016/j. ijbiomac.2017.05.171

60. Lin D, Liu Z, Shen R, Chen S, Yang X. Bacterial cellulose in food industry: Current research and future prospects [published online ahead of print, 2020 May 5]. Int J Biol Macromol. 2020;158:1007-1019. doi:10.1016/j. ijbiomac.2020.04.230

61. Taous K, Joong K, Joong HK. Functional biopolymers produced by biochemical technology considering applications in food engineering. Korean J Chem Eng. 2007;24(5):816-826. doi: 10.1007/s11814-007-0047-1

62. Abbas R, Hatam G, Hossein B. Microbial cellulose as support material for the immobilization of denitrifying bacteria. Environ Eng Manag. 2008;7(5):589-594. doi: 10.30638/eemj.2008.082

63. Mikkelsen D, Gidley MJ, Williams BA. In vitro fermentation of bacterial cellulose composites as model dietary fibers. J Agric Food Chem. 2011; 59(8):4025-4032. doi:10.1021/jf104855e

64. Jhonsy $\mathrm{G}$, Siddaramaiah. High performance edible nanocomposite films containing bacterial cellulose nanocrystals. Carbohydr Polym. 2012;87(3):20312037.doi: 10.1016/j.carbpol.2011.10.019

65. Yamanaka S, Watanabe K, Kitamura N, et al. The structure and mechanical properties of sheets prepared from bacterial cellulose. J Mater Sci . 1989;24(9):3141-3145. doi: 10.1007/BF01139032

66. Iguchi M. Bacterial cellulose, a masterpiece of nature's arts. J Mater Sci. 2000;35(2):261-270. doi: 10.1023/A:1004775229149

67. Legnani C, Vilani C, Calil VL, et al. Bacterial cellulose membrane as flexible substrate for organic light emitting devices. Thin Solid Films. 2008;517(3):10161020. doi: 10.1016/j.tsf.2008.06.011

68. Ummartyotin S, Juntaro J, Sain M, Manuspiya $H$. Development of transparent bacterial cellulose nanocomposite film as substrate for flexible organic light emitting diode (OLED) display. Ind Crops Prod. 2012;35(1):92-97. doi: 10.1016/j.indcrop.2011.06.025 69. Gutierrez J, Tercjak A, Algar I, Retegi A, Mondragon I. Conductive properties of $\mathrm{TiO} 2 /$ bacterial cellulose hybrid fibres. J Colloid Interface Sci. 2012;377(1):88-93. doi: 10.1016/j.jcis.2012.03.075

70. Basta AH, El-Saied H. Performance of improved bacterial cellulose application in the production of functional paper. J Appl Microbiol. 2009;107(6):20982107. doi: 10.1111/j.1365-2672.2009.04467x

71. Cheng KC, Catchmark JM, Demirci A. Effects of CMC addition on bacterial cellulose production in a biofilm reactor and its paper sheets analysis. Biomacromolecules. 2011;12(3):730-736. doi: 10.1021/bm101363t

72. Gayathry G, Gopalaswamy G. Production and characterisation of microbial cellulosic fibre from Acetobacter xylinum. Indian J fibre Text Res. 2014;39:93-96 
73. Chan CK, Shin J, Jiang, SXK. Development of tailor-shaped bacterial cellulose textile cultivation techniques for zero-waste design. Cloth Text Res J. 2018;36(1):33-44. doi: 10.1177/0887302X17737177

74. Hassan E, Hassan M, Abou-Zeid R, Berglund L, Oksman K. Use of Bacterial Cellulose and Crosslinked Cellulose Nanofibers Membranes for Removal of Oil from Oilin-Water Emulsions. Polymers (Basel). 2017;9(9):388. doi: 10.3390/polym9090388

75. Galdino Jr CJS, Maia AD, Meira, HM, et al. Use of a bacterial cellulose filter for the removal of oil from wastewater. Process Biochem. 2020;91:288-296. doi: 10.1016/j.procbio.2019.12.020

76. Shoukat A, Wahid F, Khan T, et al. Titanium oxidebacterial cellulose bioadsorbent for the removal of lead ions from aqueous solution. Int J Biol Macromol. 2019;129:965-971. doi: 10.1016/j. ijbiomac.2019.02.032

77. Fang $Q$, Zhou X, Deng $W$, Zheng Z, Liu Z. Free standing bacterial cellulose-graphene oxide composite membranes with high mechanical strength for selective ion permeation. Sci Rep. 2016;6:33185. doi: 10.1038/srep33185

78. Zhu C, Liu P, Mathew AP. Self-Assembled TEMPO Cellulose Nanofibers: Graphene Oxide-Based Biohybrids for Water Purification. ACS Appl Mater Interfaces. 2017;9(24):21048-21058. doi: 10.1021/

\section{acsami.7b06358}

79. Liu P, Zhu C, Mathew AP. Mechanically robust high flux graphene oxide - nanocellulose membranes for dye removal from water. J Hazard Mater. 2019;371:484493. doi: 10.1016/j.jhazmat.2019.03.009

80. Sabio RM, da Silva RR, Sargentelli V, et al. Growth of magnetic cobalt hexacyanoferrate nanoparticles onto bacterial cellulose nanofibers. J Mater Sci Mater Electron. 2019;30(18):16956-16965. doi: 10.1007/ s10854-019-02066-6

81. Hai WL, Qing FG, Zhu Z, et al. Highlyconductive and stretchable conductors fabricated from bacterial cellulose. NPG Asia Mater. 2012;4:e19. doi: 10.1038/ am.2012.34

82. Hu W, Chen S, Yang J, Li Z, Wang H. Functionalized bacterial cellulose derivatives and nanocomposites. Carbohydr Polym. 2014;101:1043-1060. doi: 10.1016/j. carbpol.2013.09.102

83. Hamed G, Eden MN, Tina N, Arben $M$. Nanocellulose in sensing and biosensing. Chem Mater. 2017; 29(13):5426-5446. doi: 10.1021/acs. chemmater.7b01170

84. Mangayil R, Rajala S, Pammo A, et al. Engineering and Characterization of Bacterial Nanocellulose Films as Low Cost and Flexible Sensor Material. ACS Appl Mater Interfaces. 2017; 9(22):19048-19056. doi:10.1021/ acsami.7b04927 